\title{
Retracted paper rattles Korean science
}

\section{Authors disagree over work aimed at gene therapy for diabetes.}

Nature this week is retracting a 2000 paper that promised an advance in diabetes treatment using gene therapy. Confusion surrounding the paper, including allegations about fraudulent data, continues to afflict the South Korean science community.

The paper's authors, led by Hyun Chul Lee of Yonsei University in Seoul, claimed to have created a treatment for type 1 diabetes, a condition in which the immune system destroys the insulin-producing cells needed to regulate glucose levels. Lee's team used a recombinant virus to introduce a gene for an insulin analogue into diabetic rats and mice, which was expressed in response to blood glucose levels and alleviated symptoms. The team suggested the treatment could be adapted for humans (H. C. Lee et al. Nature 408, 483-488; 2000).

Now, having yet to repeat the experiment, Lee has asked Nature to retract the paper (see page 660). "I don't know the reason why the experiments are not reproducible," says Lee. He suggests that the original gene construct, pLPK-SIA - a combination of the virus vector, the insulin analogue and a promoter that regulates the expression of the analogue in response to glucose levels - might have mutated after the original experiment.

The background to the retraction is contentious. A researcher who joined the laboratory in 2001 tried and failed to initiate preclinical trials in bigger animals such as dogs and monkeys. But the researcher, who does not want to be identified for fear that acting as a whistleblower could harm his career, says he didn't find any pLPK-SIA in the laboratory, so with another researcher in the lab he tried to remake it according to the methods section from the original paper. Lacking essential ingredients, they eventually gave up.

The anonymous researcher says one of the paper's authors, Su-Jin Kim, who created the gene construct before moving to the University of Calgary in Canada, refused to send him samples. Kim says she deferred on this matter to her new boss, Ji-Won Yoon. The researcher, however, says that in e-mail exchanges, Yoon told him to ask Kim for samples. Yoon, also a co-author on the Nature paper, died in 2006.

Lee fired the anonymous researcher in August 2005, citing unhappiness with his work. Lee says that in 2008 the researcher threatened to disclose faults in the paper unless given money, grants and a new job. The researcher admits that he asked for a new position

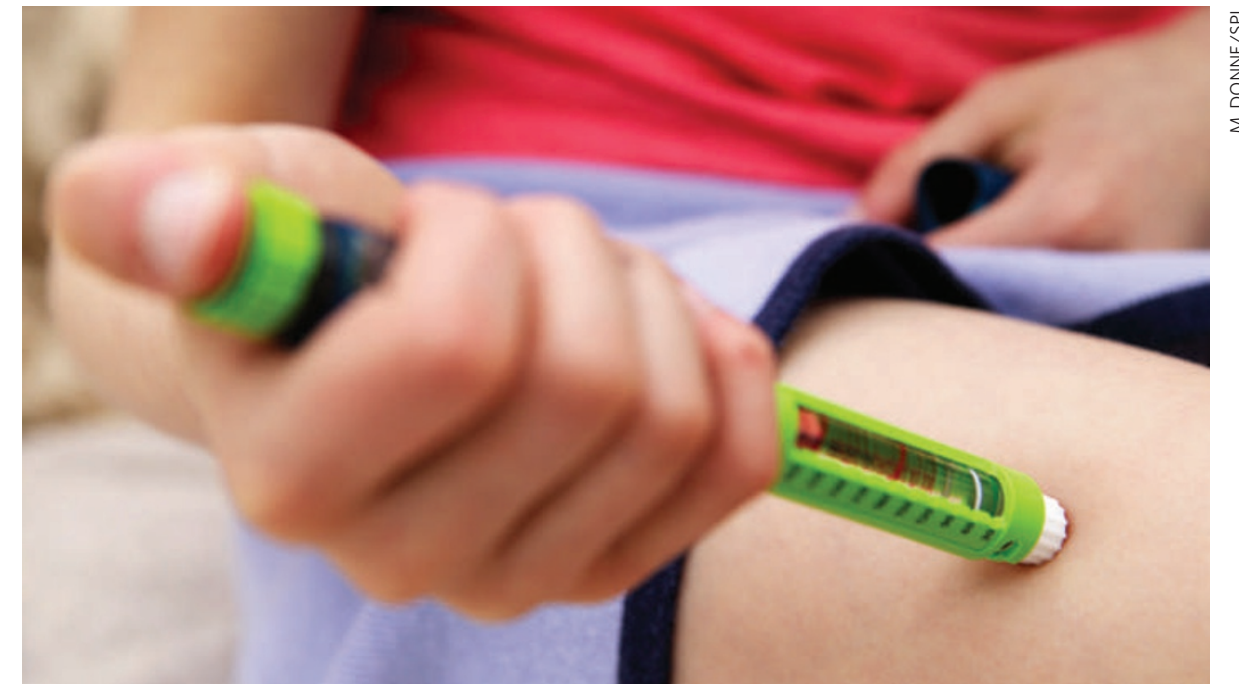

A retracted paper suggested that gene therapy could be used to treat type 1 diabetes.

as compensation for losing what he calls four-and-a-half years trying to reproduce the results. He alleges that he was fired after advising Lee to retract the paper, which Lee denies.

In April 2008, Yonsei University started an investigation, chaired by chemist Won-Yong Lee. On 30 December the committee recommended a retraction based on multiple points, including the apparent duplication of figures and the fact that it could not confirm the key construct existed when the experiment was carried out. Won-Yong Lee says that the committee members examined Kim's lab notes and thesis, and alleges that "the duplication was more than a simple mistake", including the reuse of data as well as cutting, pasting and otherwise adjusting figures. In addition, "the pLPK-SIA found in the laboratory and deposited at a cell-line bank had mutations that would make the plasmid nonfunctional", Won-Yong Lee wrote in an e-mail to Nature's news team.

The committee says that Kim and Yoon tried to reproduce the experiments; Kim, who is now at the University of British Columbia in Vancouver, says she did not, and didn't know there was a problem until last year. She says she has some of the pLPK-SIA and that the problems with figures were probably a mistake made when forwarding to colleagues, or in labelling. She faults the committee for choosing "to rely on the memory of witnesses who were testifying about experiments that took place $8-10$ years ago". Kim refused to sign the retraction letter, calling the original experiment a success, based on lab notes.
She also filed an injunction, currently under consideration in the Seoul District Court, to prevent the university releasing its full report.

Nature's policy is that it will permit retraction of a paper without the sign-on of all authors, while making clear which authors disagree with the retraction. A Nature spokesperson notes that underlying problems with a paper, if they exist, can be difficult to detect through standard peer review.

Won-Yong Lee says that the university ethics committee will decide whether any of the researchers involved will be censured after the court reaches a decision, expected within a few months, regarding the injunction.

The anonymous researcher faults the committee for, in his view, refusing to investigate several other alleged problems with the paper. Two months ago, he sent a letter of complaint to the Korea Research Foundation, which funded the research, but has yet to hear back. "Yonsei University investigated into the case in a way that generated minimal damage against Yonsei University," he comments. Won-Yong Lee disagrees strongly, saying that the committee had members from other institutions that had no vested interest in protecting Yonsei University or Hyun Chul Lee.

The researcher and Kim agree that reproducing the experiment would resolve the situation. Kim says she will ask her current boss to share pLPK-SIA samples with other researchers to do just that.

David Cyranoski 